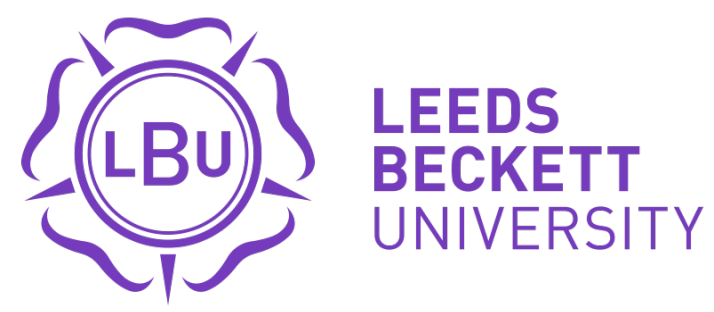

Citation:

Robinson, SJ (2014) John R. Wooden, Stephen R. Covey and Servant Leadership A Commentary. International Journal of Sports Science and Coaching, 9 (1). 37 - 38. ISSN 1747-9541 DOI: https://doi.org/10.1260/1747-9541.9.1.37

Link to Leeds Beckett Repository record:

https://eprints.leedsbeckett.ac.uk/id/eprint/1956/

Document Version:

Article (Published Version)

The aim of the Leeds Beckett Repository is to provide open access to our research, as required by funder policies and permitted by publishers and copyright law.

The Leeds Beckett repository holds a wide range of publications, each of which has been checked for copyright and the relevant embargo period has been applied by the Research Services team.

We operate on a standard take-down policy. If you are the author or publisher of an output and you would like it removed from the repository, please contact us and we will investigate on a case-by-case basis.

Each thesis in the repository has been cleared where necessary by the author for third party copyright. If you would like a thesis to be removed from the repository or believe there is an issue with copyright, please contact us on openaccess@leedsbeckett.ac.uk and we will investigate on a case-by-case basis. 


\title{
John R. Wooden, Stephen R. Covey and Servant Leadership
}

\author{
A Commentary \\ Simon Robinson \\ Leeds Metropolitan University \\ The Rose Bowl, Leeds, LS1 3HE, UK \\ E-mail: s.j.robinson@leedsmet.ac.uk
}

\section{INTRODUCTION}

This is a rich article. I enjoyed it because of the connections that it makes, between leadership and coaching, and virtues, character and sporting practice. There is too much to do the whole article justice so I will dive in to focus on four aspects: spirituality, servant leadership, virtues and leadership, and development in leadership theory.

\section{SPIRITUALITY}

There is no doubt that both Covey and Wooden take us into some form of spirituality. At the very least Covey wants to take us beyond principle and prescription and into underlying vision and paradigms. This takes us beyond science and descriptive theory to value and values, to living out those values in virtues and focus on experience and narrative. I am very happy with that, and the focus on qualitative research. However, lurking beneath that are several assumptions, not least about what spirituality is. Crust [1], Paley [2], and Robinson and Smith [3] in different contexts argue that there is a lack of rigour in the use of the term spirituality. The problems range from: acceptance of an implied religious spirituality (something not totally resolved in Wooden or Covey, or in US academic response to spirituality at work and in healthcare generally); assumptions, either about the existence of a spiritual aspect of humanity, often contrasted with psychological or physical aspects (leading to a form of dualism that is very hard to sustain); assumptions about the relationship of spirituality to holism (often simply equating the two); and the assumption that spirituality is based largely in altruistic care.

The importance of care is strongly argued by Wooden, involving commitment over time to, and a respect for the dignity and autonomy, of the follower or person being coached. And this can be seen as proper in itself, regardless of claimed good consequences (see Rosen [4] for a rich treatment of this from a Kantian perspective). However, it is not always clear what this involves. Is it unconditional care, or care which goes the extra mile? How does care affect ideas of contract, and how might 'care' be involved in dealing with stakeholder conflict? The point is that the treatment of the connection between care and spirituality, and from that to good outcomes, is often otiose. In a recent book [3], I have argued that this demands more conceptual and empirical rigour, leading to questioning of spirituality research which simplistically connects spirituality and well-being. 


\section{SERVANT LEADERSHIP AND VIRTUES}

This same theme moves across to servant leadership, which is often focused in altruistic care and on putting the followers first. There are real problems with this; from a lack of theoretical base [5] to a lack of critical engagement. Greenleaf's [6] original work, for instance, tends to conflate the role of a servant (who is concerned for the needs of the group) and the role of leader (who is precisely focused on a wider stakeholder population, often involving having to deal with conflict between these stakeholders). Implicit in early servant leadership approaches is also an uncritical view of altruistic love and a great stress on moral virtues. That is fine as far as it goes, but lacks appreciation of complexity in the social and physical environment, and, with that, lacks focus on the intellectual virtues. Hence, I would argue that the stress in Jenkins's article on the importance of intellectual as well as moral virtues is critical. One of the key points about Aristotelian practical wisdom (phronesis) is that it is precisely seen by Aristotle as an intellectual virtue, not a moral virtue. This means that reflection on the good is always a critical exercise, including on-going critical reflection on values and underlying myths which inform our perspectives of the good. In turn this suggests that phronesis is essentially social and dialogic.

The stress on all the other intellectual virtues highlighted by Jenkins is also fascinating, not least because this reminds us of the importance of focusing also on the project that is shared by participants and the need to test meaning and practice. For leaders of professions this also means focus on the purpose of the profession, which in some way may be focused in the common good (through values such as health or justice). Such a purpose may in itself be more important than simple focus on the needs of the follower. Indeed, such a purpose might challenge the follower.

\section{CONCLUSION}

This moves us beyond a simple idea of servant leadership to one which is essential dialogic and challenging. I would argue that it brings us back to the need to address complexity in leadership [7]. Complexity theory focuses on the many different narratives and practices which are part of the social environment, and which may contribute to or challenge the meaning and value of any project, including the practice of sport. Hence, this remains directly relevant to coaching.

\section{REFERENCES}

1. Crust, L., Challenging the Myth of a Spiritual Dimension in Sport, Athletic Insight - Online Journal of Sport Psychology, 2006, 8(2), 17-31, http://www.athleticinsight.com/Vol8Iss2/Spiritual.htm

2. Paley, J., Spirituality and Nursing: A Reductionist Approach, Nursing Philosophy, 2008, 9, 3-18.

3. Robinson, S. and Smith, J., Co- Charismatic Leadership: A Critical Examination of Spirituality, Ethical Values and Leadership, Peter Lang, Oxford, UK, 2014.

4. Rosen, M., Dignity: Its History and Meaning, Harvard University Press, Harvard, MA, 2012.

5. Polleys, M., One University's Response to the Anti-Leadership Vaccine: Developing Servant Leaders, Journal of Leadership and Organizational Studies, 2008, 8, 117-131.

6. Greenleaf, R., The Servant as Leader: A Journey into the Nature of Legitimate Power and Greatness, Paulist Press, New York, 1977.

7. Schneider, M. and Somers, M., Organizations as Complex Adaptive Systems: Implications of Complexity Theory for Leadership Research, The Leadership Quarterly, 2001, 17, 351-365. 